\title{
Lexic-semantic Features of Sport Terms
}

\author{
Navbahor Qo'ldosheva
}

\begin{abstract}
This article discusses the role of terminology in linguistics, lexical-semantic aspects of sporting terms, and the importance of sports in the development of personality.
\end{abstract}

Keywords : terminology, category, concept, ethnolinguistics, psycholinguistics, neurolinguistics, linguopragmatics, cognitive linguistics, communicative linguistics, gender linguistics.

\section{INTRODUCTION}

$I_{t}$ is worth noting that achievements in the rapidly evolving world of linguistics, including a number of studies, concepts, terminology, categories, theories, cognitive linguistics , communicative linguistics, gender linguistics, ethnolinguistics, psycholinguistics, gender linguistics, linguoculturology and linguopragmatics. It allows to conduct scientific researches in modern directions. "As the human mind grows, so does its outlook and thinking.

As every science develops, linguistics is evolving day by day, causing new trends, schools, new scientific theories. "In addition, there is a certain tendency in each science.The emergence of interdisciplinary cognitive linguistics, linguoculturology, and interpersonal communication theory further expands the tasks of interdisciplinary linguistics and writes about the new tasks of interdisciplinary linguistics".

\section{MATERIALS AND METHODS}

Ethnolinguistics, linguopragmatics are the methods of our research and the terms used in sport are the materials to be analysed. It is well-known that through language, a person receives, collects, processes, regulates and perceives information about existence and reality. Through the language, a person communicates with other nationalities and learns a different culture, and language is not only a means of communication, but also a means of formulating and expressing culture.

\section{DISCUSSION}

The term "terms" comes from the Greek word "terminos", which means a check, a border. The term terminology and the field that studies these terms is called "terminology."

In recent years in Uzbek "atama" (nominative unit) has been used instead of the word "term". Such an application is a mistake. Because the meaning of the term is broader than the meaning of the nominative unit, it is understood as the name of all things, and the term is a formal word used in a particular field. Therefore, it is appropriate to refer to the word "term" in terminology as a unit of vocabulary with the scientific and official meaning that is included in the term.

The time itself shows that in the face of today's ever-increasing tensions, it is more important than ever to increase our youth's spiritual immunity and meaningfully spend their leisure time.

Therefore, 5 important initiatives put forward by the President of the country Sh.Mirziyoev to set up work in social, spiritual and educational spheres on the basis of a new system are of great importance.

The first initiative is to promote the interest of young people in music, painting, literature, theater and other arts, as well as reveal their talents.

The second initiative is aimed at creating the necessary conditions for the physical education of young people and their ability to perform in sports.

A third initiative is to promote the effective use of computer technology and the Internet between the population and youth.

The fourth initiative is aimed at creating a systematic work to improve the spirituality of young people, and to popularize reading among them.

The fifth initiative addresses employment of women.

The most important initiative is the organization of sporting events for mass sports and physical training;

- Centralized purchase of necessary technical equipment, sports equipment, inventory and other necessary equipment for departmental sports organizations and educational institutions within the Committee;

- centralized purchase of medals, diplomas, trophies and prizes necessary to reward winners and prize-winners of international and national championships, trophies, tournaments, and sporting events;

- awarding sportsmen, trainers, and other specialists in the field of physical culture and sports, as well as sports teams of sports facilities of the Republic with sports titles and qualification categories, awarding trophies, medals, medals, badges, diplomas, prizes and prizes;

- provides the organizations with funds for the organization of physical training, sports and physical training events, preparation of sportsmen for participation in various competitions, sports competitions and the like.

It provides full support for the development of national sports and folk games in Uzbekistan, provides financing for the organization and conduct of national and international sports, as well as the promotion and development of national sports on the international sports arena. 
This will improve the system of selecting, training and improving the skills of talented and promising athletes in our country, to provide them with high-quality sports resources and national teams to ensure successful participation in the Olympic, Paralympic and Asian Games, World and Asian Championships and other prestigious international competitions and tournaments. gives more opportunities for molding.

In this regard, the expansion and strengthening of interstate and international sporting relations in the field of sports, the attraction of foreign investments and grants in the field of physical culture and sports, the promotion of popular sports programs, the publication of popular literature in the field of physical culture and sports, accelerates the creation of materials.

Also, the organization of training, retraining and advanced training of personnel in the field of physical culture and sports, the provision of physical training and sports organizations, educational and sport-educational institutions with highly qualified trainers and other sports specialists. development and strengthening of material and technical basis, organization of production of local sports equipment and inventory.

Obviously, sport has a special impact on the development of a person, promotes the development of life skills and skills, promotes spiritual, moral and intellectual growth, and reinforces the personality traits of courage, will, and spirituality. help, generosity, honesty, the spirit of internationalism and many others are the most important qualities of sports. Indeed, the role that sport plays in our lives is invaluable. It plays an important role in the spiritual and physical development of a person.

Sport has always had a number of important tasks in front of society, and in short, it is a personal competition, and in a broad sense it is the special training and the norms and achievements that the individual sporting activities are based on. Sports Games (Competition Exercises) In other words, there are sports that can be classified according to the amount of medals being played (gold, silver, bronze).

Athletics, swimming, gymnastics, academic rowing, boxing and more are all types of sports with high medals. But at the same time, the Olympics compete for one gold, one silver and one bronze medal. Sports can also be classified according to the method of determining the results of the competition.

Group 1 - sport based on meter measurements: track and field athletics, weightlifting, cycling, alpine skiing, skiing, equestrian sport and more.

Group 2 - sports whose results are evaluated according to their accuracy, beauty, sense of purpose, amplitude of movement - gymnastics, acrobatics, figure skating and more.

Group 3 - martial arts and sports. The groups are grouped by sport and in turn: - limited-time activities (football, hockey, basketball, handball, etc.); - limited results (volleyball, tennis, table tennis, etc.); - types that can be won until a limited time (boxing - knockout, wrestling - pure victory).

Group 4 - multidimensional sports (All-Athletics, Modern Pentathlon, Biathlon, Skiing, Two Fights, etc.).

The multifaceted nature of the grouping of sports exercises allows using one or another type of detail, depending on the nature of the issues being addressed. It is most commonly used in sports recreation or in the body's special regeneration system, as a factor in the fight against fatigue, in meeting emotional needs and in restoring the temporarily lost functionality of the body. "Kurash is a symbol of nobility, bravery and honesty from ancient times, it is a part of the national cultural heritage of our people for thousands of years.

The first information about the struggle can be found in skyscrapers, rocks and caves, reflecting the samples of fine art found in Surkhon and Zarafshan oasis, Ferghana valley and Sarmishsai gorge. During the great commander Amir Temur's struggle was one of the main ways to improve the military and physical training of soldiers. Such wrestlers as Pahlavon Mahmud, Jaloliddin Manguberdi, Darveshmuhammad have made the world famous.

Kurash is not only a sport, but it has been respected for centuries as an embodiment of courage, dedication, nobility and honesty. It is an integral part of our lives, which shows courage, strong will, honesty and respect for the opponent. As a result of direct support of our state, Kurash is widely recognized as an international sport. took place.

The football game, which became known in Egypt and the East, and later in Europe, was developed in 1848 by Cambridge University teachers in Britain. with the team.

Taekwondo is derived from the Korean word "tae" - foot, "kwon" is a hand, "do" is a type of sports wrestling. We know that both men and women compete individually and collectively for a single-leg or shot-to-action showdown on their respective weight categories and demonstrate their ability to perform special exercises.

The word "Shaxmat", as "shox mot" (chess) from Persian is king sport. The goal of the game is to mock the opponent's king. It is played on 64 equal-sized planks (white and black) in 16 different colors (one royal and pharynx, 2 zinc, elephant and horse, 8 foot). The origin of chess goes back to "chaturanga". During the Arab Caliphate the game was popularized as "shatranj". As the Arabs introduced the chess record, it is known that valuable information on the text of the chess game has been preserved.Abulfath Ahmed ibn Sijzi wrote in his book "Shatranj haqida kitob" about the first chess tournament held in Khurasan in 819 and the famous Central Asian chess player Abu Bakr as-Sulli. It is possible to say that As-Sulli coached Abulfaroj Layloj, a hero of many chess events. Boxing, as you know, means boxing, punching. The history of boxing goes back to the history of boxing in Egypt and Babylon in the BC. There were similar competitions in the ancient Olympic Games in Greece. Modern boxing is very popular in England.

Japanese "karate"- meaning hand-to-hand fighting - is a form of sports-based wrestling that is based on self-defense without arms and bumps with the hands or feet on sensitive areas of the human body. The current rules of karate were based on the improvement of Japanese jiujitsu martial arts in the early 20th century.

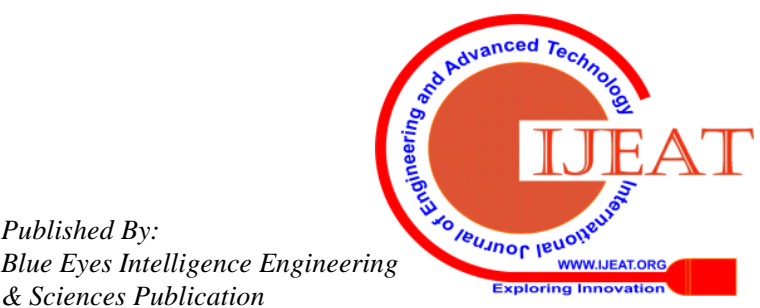


Its first methods and rules were developed by the Japanese scientist G.Funakosi, who lived in 1869-1957.

Freestyle skiing is a freestyle, English style. There are three types of freestyle: mogul, ski ballet, and acrobatics. Freestyle in Uzbekistan began to be popular in the early 1990s. Vasila Semenchuk was the world champion in 1991.

Judo - Japanese "judo" - soft, "do" - road - martial arts. In 1882 the Japanese professor Dzigoro Kano was founded. He has taken Japanese jiu-jitsu techniques that are not harmful to human health and has shaped Judo as a sport that promotes physical growth. The judoists will be wearing a kimono and compete on a tatami (carpet) on bare feet. When standing up, competitors try to score each other using methods such as playing, shaking, jumping, and so on.

While lying down, using the techniques of twisting, pain, and stroke are allowed to cope with the opponent's shoulders for 30 seconds. Depending on the methods, wrestlers will be awarded "koko", "yuko", "vasari" and "ippon" ("ippon" is a pure victory, two "vassari" are victories, and "yuko" and "koko") are awarded. is considered).

Handball is a German hand - hand, ball is a ball, a handball is a sports game. This sport originated in Europe in the late 19th century. Invented by Danish Halger Nielson (1898). Greek acrobats are acrobats, which means walking up and down. It is a kind of gymnastics. Skiing is one of a number of special types of sports that can be performed with or without the help of sports equipment.

Russian Sambo- unarmed self-defense is a sport. It is based on the most effective methods of national wrestling. Sambo is allowed to remove his opponent's hands and feet, and to move with his feet and legs, hands and body.

Biathlon (Greek bi and athlete - race) Winter sports, skiing and shooting at certain races, that is, racing twice (ski racing and shooting). Biathlon was originated in Norway in the 1770s. In 1718 Sweden was a fully armed Biathloner on the battlefield in the Norwegian War. Still on the coat of arms of the Norwegian city of Lillexamer there is an image of a skier. Biathlon has long been considered a "military sport." In 1948, the International Association for Contemporary Rowing and Biathlon (UIPMB) was established, with more than 70 countries members (1991). Competitions for the world championship are held since 1958 and included in the program of the Winter Olympics from 1960. Women's World Cup 1984 (France) Basketball - English Basketball - Basket, Ball - Ball) is a sports game, hand-held ball game in a basket ring with a height of 3.05 meters.

Basketball has been playing in Uzbekistan since 1921. R. Salimova from Uzbekistan was twice the champion of the world and Olympic Games.

Volleyball is an English volley ball, a volleyball is a hit game, and a ball is a sports ball game.

Bodybuilding, Culturism - English. Body Building - Body Structure - Sports. Body muscles like dumbbells, sleds, stones and so on. It is a system of exercises designed to develop, to make it beautiful and invigorating, with such emphasis was first placed on Greece and ancient Rome. At the end of the 19th century Great Britain developed the basics of modern culture - French culturisme and English physical culture physical culture)

\section{CONCLUSION / RESULTS}

IIn conclusion, to create a healthy lifestyle in our society, to create the conditions necessary for regular training of the population, especially the young generation in physical culture and mass sports, to strengthen confidence in their will, strength and capabilities in youth through sporting events, courage and patriotism. as well as large-scale work on the systematic selection of talented young athletes and further development of physical culture and mass sports. It is encouraging that, as well as the achievements of world linguistics, the creation of a number of studies.

\section{REFERENCES}

1. Жўраева М.М.Француз ва ўзбек тилларида модаллик категориясининг лингвокогнитив, миллий-маданий хусусиятлари. Док.дисс.филол.2017. - Б.45

2. Юсупов У.К. Теоретические основы сопоставительной лингвистики. -Т.: Фан, 2007. - С.123

3. "Халк сўзи", 2017 йил 3 октябрь.Ўзбекистон Республикаси Президентининг "Кураш" миллий спорт турини янада ривожлантириш чора-тадбирлари тўғрисида"ги қарорига шарх 